\title{
A Probit Analysis of Determinants of Adoption of Improved Sorghum Technologies Among Farmers in Tanzania
}

\author{
Thedy Gerald Kimbi ${ }^{1,2}$, Essegbemon Akpo ${ }^{1,3}$, Eliud Kongola ${ }^{2}$, Chris O. Ojiewo ${ }^{1}$, Ronnie Vernooy ${ }^{4}$, \\ Geoffrey Muricho ${ }^{1}$, Justin Ringo ${ }^{2}$, Gerald Alex Lukurugu ${ }^{2}$, Rajeev Varshney ${ }^{1}$ \& Ramadjita Tabo ${ }^{1}$ \\ ${ }^{1}$ International Crops Research Institute for the Semi-arid Tropics, Patancheru, Telangana, India \\ ${ }^{2}$ Tanzania Agricultural Research Institute, Dodoma, Tanzania \\ ${ }^{3}$ Ecole de Gestion et de Production Végétale et Semencière, Université Nationale d'Agriculture, Kétou, Bénin \\ ${ }^{4}$ Alliance of Bioversity International and CIAT, c/o Wageningen University and Research Center, Wageningen, \\ Netherlands \\ Correspondence: Essegbemon Akpo, International Crops Research Institute for the Semi-arid Tropics, \\ Patancheru 502 324, Telangana, India. E-mail: akpo.essegbemon@gmail.com; e.akpo@cgiar.org
}

Received: October 3, $2020 \quad$ Accepted: November 6, $2020 \quad$ Online Published: December 15, 2020

doi:10.5539/jas.v13n1p73 URL: https://doi.org/10.5539/jas.v13n1p73

\begin{abstract}
The adoption of improved sorghum technologies by smallholder farmers is still low in Tanzania. Many farmers fail to acquire quality inputs due to different underlying reasons. This article analyzes factors underlining the adoption of improved technologies among sorghum farmers in Tanzania and evaluates profitability of grain production. A total of 212 individual farmers were interviewed through structured questionnaires from nine districts. Data were analyzed using descriptive statistics, probit regression model and gross margin analysis. Results show that $39.2 \%, 26.5 \%, 16.9 \%, 8.4 \%$ and $7.2 \%$ of sorghum farmers adopted seeds of improved varieties, insecticides, inorganic fertilizers, threshing machine and optimum seed rate, respectively. Probit estimates indicated that age, sex, number of years in school, group membership, farm size, availability of free seeds, seed accessibility, grain market accessibility and grain market price were the significant factors influencing adoption of these technologies. Adopters obtained higher profitability $(822,288 \mathrm{Tsh} / \mathrm{ha})$ than non-adopters $(374,363 \mathrm{Tsh} / \mathrm{ha})$ of improved varieties. Further policy actions are needed to improve determinants of adoption, breeding technologies and accessibility of agricultural inputs to ensure benefits to farmers and the sorghum sub-sector.
\end{abstract}

Keywords: profitability, smallholder farmers, seeds of improved varieties, technologies, Tanzania

\section{Introduction}

The agricultural sector contributes to $32.4 \%$ of GDP and occupies over $70 \%$ of smallholder farmers in Tanzania (Faura, 2016). Smallholder farmers cultivate about 5.1 million hectares annually for both subsistence and cash crops (Muyanga \& Jayne, 2017). This explains the importance of smallholder farming in Tanzania and the need for continuing investments and improvement to support sustainable agriculture, poverty reduction and nutritional goals (Msangi, 2017). Sorghum is highly grown in semi-arid regions in Tanzania primarily for food consumption and commercial purposes. It is the third most important cereal crop with a total production of 812,488 hectares and over 500,000 tons per year in the country (FAO [Food and Agricultural Organization], 2018). Sorghum production in the country still need efforts for improvement since many farmers fail to reach attainable yield and profit levels due to factors such as unfavorable climatic changes, pests, diseases and poor technologies (CCAFS [Climate Change Agriculture and Food Security], 2015).

The growing demand for sorghum crop as a raw material for nutritious food products and brewing industries, and Tanzania being among leading sorghum producers in Africa, it creates an opportunity for farmers to obtain profit from its production. Sorghum demand is expected to double to two million tons by 2050 to make Tanzania a net exporter (Orr et al., 2016). Promoting sorghum as a food security and commercial crop highly requires investments in production technologies and new market opportunities (Aloyce et al., 2017).

A wide range of technologies such as seeds of improved varieties, mechanization and agrochemicals have been introduced by the Government and development institutions (URT [United Republic of Tanzania], 2016). 
Improved technologies are continuously introduced and promoted to improve agricultural gains and higher returns among farmers (Simtowe \& Maush, 2018). Despite these efforts, most farmers have not widely adopted improved technologies. Low adoption rates of improved varieties and other technologies have been attributed to low availability and income levels to purchase the technologies that have resulted into low production and market difficulties (Elsheikh et al., 2018). Adoption of improved sorghum varieties has been reported to be low among farmers due to different reasons. Many studies have reported age, income, cooperative membership, education, resources, extension services, subsidies and output markets to influence adoption among farmers (Mpangwa, 2011; Simtowe \& Mausch, 2018; Kaliba et al., 2018). However, there has been limited empirical information on factors influencing adoption of other improved technologies apart from improved sorghum varieties in the country. Studies by Kaliba et al. (2018), Simtowe and Mausch (2018) have only assessed factors affecting varieties adoption in sorghum production in Tanzania, and this calls for more studies to further understand factors determining adoption of improved technologies. The main objective of this study is to assess determinants of adoption of improved sorghum technologies by farmers in Tanzania. Specifically, the study focuses on analyzing adoption rates of sorghum improved technologies, factors influencing adoption decision among farmers and profitability differences among adopters and non-adopters of improved varieties. Information from the study will contribute to informed and optimal policy decisions for investments and improvement of the sorghum commodity value chain.

\section{Theoretical Framework}

One would define the adoption of advanced technologies by a farmer as the situation it is used for at least one production season (Ogunyemi \& Ojo, 2014). Theoretically, adoption studies are generally based on different theories (Ghadim \& Pannell, 1999). This study is theoretically built under two theories, i.e., diffusion of innovations theory and utility maximization theory.

\subsection{Diffusion of Innovations Theory}

Diffusion of a new technology takes a process at which technology is communicated over time among participants in a social system (Rogers \& Stanfield, 1968). Technology adopted is expected to be converted into valuable output increase (productivity, profitability and income levels). The adoption process comprises of five main stages (Rogers, 2003). The theory provides principal foundation for understanding innovation diffusion in agricultural production (Petry et al., 2019). It is assumed that farmers as participants of agricultural technologies follow through these five stages: knowledge, persuasion, decision, implementation and confirmation stage (Rogers, 2003). Technology uncertainty among farmers may diminish over time through the stages, and the production function itself may change as adopters become more efficient in using the technology (Feder and Umali, 1993). Adoption decision made by a farmer before the implementation stage is usually assumed to be subjective while after this stage decision made is assumed objective (Rogers, 2003). Ugochukwu and Phillips (2018) argues that decision made after the implementation stage is based upon factual evidence, also further decision can be made on continuation or discontinuation of technology use.

\subsection{Utility Maximization Theory}

Any entity is said to be driven by its utility maximization when adopting a new technology (Nicholson and Snyder, 2008). In agricultural production, farmers are expected to make decisions on technologies use basing on their expected maximum utility. Farmers will look for necessary production technologies with minimum costs while expecting to attain increased levels of production, profits and improved food and nutrition security.

The utility function can be expressed as shown below:

$$
U_{i y}=X_{i} B_{y}+n_{i y} \quad y=1,0 ; i=1, \ldots n
$$

where,

$X_{i}$ is a farm-specific function; $B_{y}$ is a parameter for estimation; $n_{i y}$ is an error term with zero mean and a constant variance.

The adoption is assumed to be a dynamic decision since it is considered by a farmer over a number of seasons (Federal et al., 1985). Since adoption is a binary dependent variable (1 or 0), a farmer is expected to abandon traditional technology over new one only if utility expected of a new technology is greater than a former one (Awotide et al., 2016).

$$
y=1 ; \text { if } U_{i 0}<U_{i 1}
$$

where,

$U_{i 0}$ is utility obtained from traditional technology; $U_{i 1}$ is utility obtained from an improved technology. 
A farmer having a subjective perception of expected benefits of a new technology for next seasons, information on some attributes such as costs, yield and prices is likely to reduce uncertainty, although in reality, a farmer will still be uncertain of some other attributes (Ghadim \& Pannell, 1999). Since the expected utility is indirectly observable, therefore vectors of observable farmers attributes are used in explaining adoption (Diiro et al., 2015; Awotide et al., 2016). A number of these attributes represent farmers' adoption decision as well as capturing risk sensitivity (Kalinda et al., 2014). Some of these attributes include age, education, sex, farm size, income, credit accessibility, farmer group memberships and other connections (Kalinda et al., 2014). Melesse (2018) also argues that factors affecting adoption can be categorized into farmer characteristics, institutional and factors related to technology performance.

Hypothesized variables of adoption of this study are based on theoretical and empirical frameworks of previous studies (Federal et al., 1985; Ghadim \& Pannell 1999; Mpangwa, 2011; Kalinda et al., 2014; Ghimire et al., 2015; Awotide et al., 2016; Kehinde \& Adeyemo, 2017; Simtowe \& Mausch, 2018; Kaliba et al., 2018). In the study, the relationship among variables can be conceptualized into two main hypotheses: (i) HA1: Factors such as age, sex, number of years at school, group membership, production purpose, farm size, free seed availability, grain market accessibility and seed accessibility strongly influence farmers' adoption decision; (ii) HA2: Adoption of improved sorghum varieties incurs higher profitability levels among farmers.

For testing the first hypothesis, we used the probit regression model. Probit model is used in case one has observed a binary dependent variable. The model can be conceptualized as a way of presenting factors influencing farmers' adoption decision of improved technologies. Many studies (e.g., Ghimire et al., 2015; Tsinigo \& Berman, 2017; Simtowe \& Mausch, 2018) have assessed adoption under utility maximization theory, and also used probit model in explaining the significance of different factors influencing farmers adoption decision. The second hypothesis was tested using gross margin analysis. This evaluates economic viability of any farm enterprise (Wango et al., 2016). Profitability of introduced agricultural technologies is a necessary factor to be accounted for in adoption study (Kaliba et al., 2017). Some studies (e.g., Rao et al., 2017; Aloyce et al., 2017; Engwali et al., 2019) have used gross margin analysis to shed light on the profitability of improved varieties since gross margin is a proxy for profitability.

\section{Methods of Data Collection and Analysis}

\subsection{Study Area and Sampling Technique}

The study was conducted in 2019 across nine districts that are among sorghum leading producing regions in Tanzania. Sorghum districts selected for the survey included Mkalama, Singida DC, Iramba, Ikungi, Serengeti, Rombo and Momba as the project's (HOPE II) intervention districts while Kongwa and Tarime were selected as non-intervention districts (Figure 1). 


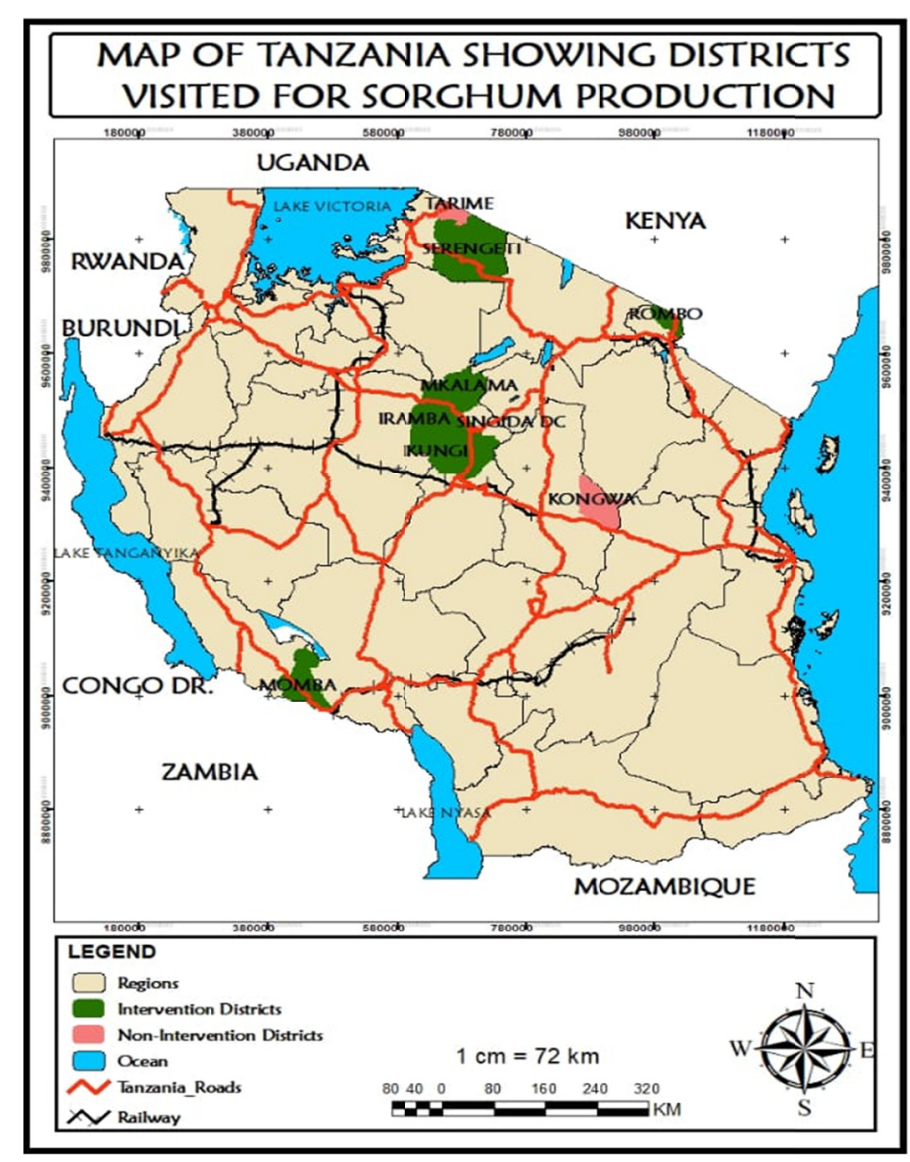

Figure 1. Map of Tanzania showing districts visited for sorghum farmers' interview

A four-stage stratified sampling technique was used to select the study sites. The first stratum was the administrative zones, followed by the regions, districts and the villages strata. This technique was used following the importance of sorghum production and implementation of the sorghum dissemination project. For nine sampled districts, we selected seven experimental districts with introduced improved varieties under the project and two control districts. A total of 18 villages from nine districts were selected based on the importance of sorghum production. Farmers were then selected randomly from these villages. A list of 450 sorghum farmers from 18 villages was obtained with the help of village executives and was used as the population within which the sample was drawn. Table 1 shows the distribution of the 212 interviewed farmers across nine selected districts.

Table 1. Distribution of sorghum farmers interviewed across nine selected districts $(\mathrm{n}=212)$

Note. n: sample size.

\begin{tabular}{ll}
\hline District & Farmers (n) \\
\hline Mkalama & 30 \\
Singida DC & 28 \\
Iramba & 18 \\
Ikungi & 10 \\
Serengeti & 26 \\
Rombo & 18 \\
Momba & 38 \\
Kongwa & 38 \\
Tarime & 6 \\
\hdashline Total & 212 \\
\hline
\end{tabular}


Furthermore, sample size determination formula used in the study to obtain 212 farmers was the one presented by Yamane (1967) as the formula is said to be reliable by $95 \%$. The formula is expressed as shown below where by $n$ represents the sample size determined, $\mathrm{N}$ represents the population size and e represents the error term that is 0.05 .

$$
\begin{gathered}
n=\frac{N}{1+N e^{2}} \\
n=\frac{450}{1+450(0.05)^{2}}
\end{gathered}
$$

where, $n=212$ sorghum farmers.

\subsection{Data Analysis}

Data were analyzed using SPSS version 20 and STATA version 13 softwares. The analysis was done through descriptive statistics, probit model and gross margin analysis. Descriptive statistics were used to analyze farmers' socio-economic characteristics and current rates of adoption of improved sorghum technologies. Probit model was fit to estimate adoption decisions since the response dependent variable is a binary one. Dependent variable of the model comprised of a dummy variable that represents given technologies in the study. These technologies included seed of improved varieties, optimum seed rate, inorganic fertilizers, insecticides and threshing machine. Independent variables included in the model were age, sex, education, group membership, production purpose, farm size, seed price, free seeds availability, grain market accessibility and seed accessibility (Table 2). Independent probit regression models can be used to assess adoption of more than one improved technology (Kehinde \& Adeyemo, 2017). The model is appropriate since it can resolve the problem of heteroscedasticity and satisfies the assumption of cumulative normal probability distribution (Gujarati, 2004).

The probit model can be specified as shown below (Equation 5):

$$
\begin{gathered}
Y_{i}=\mathrm{F}\left(X_{i} \beta\right)+\varepsilon_{i} \\
Y_{i}=\left\{\begin{array}{l}
1, \text { if adopted } \\
0, \text { otherwise }
\end{array}\right.
\end{gathered}
$$

where,

$\varepsilon \sim \mathrm{N}(0,1) ; \beta=$ maximum likelihood; $\varepsilon=$ error term; $X=$ set of independent variables included in the model.

Since estimates of the probit model provide only direction of effects, the marginal effects are usually calculated to interpret the actual change in probability of independent variables.

$$
\text { Marginal effects }=\beta_{i} \phi(z)
$$

where,

$\beta_{i}=$ coefficients of the variables; $\phi(z)=$ cumulative normal distribution value associated with the mean dependent variable from the probit estimation.

Table 2. Independent variables of the probit model and their expected signs

\begin{tabular}{lll}
\hline Variable & Measurement & Expected sign \\
\hline Age & Years (continuous) & $+/-$ \\
Sex & Dummy $(0=$ female, $1=$ male $)$ & + \\
Years in school & Years (continuous) & + \\
Group membership & Dummy $(0=$ no, $1=$ yes $)$ & + \\
Production purpose & Dummy $(0=$ subsistence, $1=$ commercial, $2=$ subsistence \& commercial) & $+/-$ \\
Farm size & Hectares (continuous) & + \\
Seed price & Tshs (continuous $)$ & - \\
Free seeds availability & Dummy $(0=$ no, $1=$ yes $)$ & + \\
Grain market accessibility & Dummy $(0=$ no, $1=$ yes $)$ & + \\
Grain prices & Tshs (continuous $)$ & + \\
Seed access & Dummy $(0=$ no, $1=$ yes $)$ & + \\
\hline
\end{tabular}

The profitability of production among adopters and non-adopters of improved sorghum varieties was computed by gross margin. The analysis is regarded as the difference between the annual total revenue for each farmer and the variable costs directly associated with them (Obayelu \& Ajayi, 2018). The total revenue represents the 
product of the amount harvested for each farmer and the unit price of sorghum grain. The total variable cost represents a summation of variable costs associated sorghum production. These costs include seeds, fertilizer, insecticides, rented land, hired labor, transport, packaging and rented threshing machines costs (Equation 7).

$$
G M_{i}=T R_{i}-T V C_{i} \quad i=1, \ldots n
$$

where,

$G M_{i}=$ Gross margin for the $i^{\text {th }}$ sorghum farmer (Tshs); $T R_{i}=$ Total revenue for the $i^{\text {th }}$ sorghum farmer (Tshs); $T V C_{i}=$ Total variable cost for the $i^{\text {th }}$ sorghum farmer (Tshs).

\section{Key Findings and Analysis}

\subsection{Socio-economic Characteristics of Sorghum Farmers}

The proportion of male farmers $(62.3 \%)$ was higher than female ones whereby male household head had full land ownership (Table 3). The age distribution shows that most of the respondents (51.9\%) were 45 to 65 years old. The number of years spent in school by most farmers was 1 to 7 years. The majority of farmers $(50.5 \%)$ were smallholders who owned less than 0.5 ha. Most farmers (60.4\%) didn't belong to any farmer group, but also, about $56 \%$ farmers produced sorghum for subsistence purpose only. Furthermore, about $61 \%$ farmers lacked access to reliable markets and around $77 \%$ didn't have access to seed of improved varieties at the right time.

Table 3. Socio-economic characterization of sorghum farmers $(\mathrm{n}=212)$

\begin{tabular}{|c|c|c|}
\hline Household variables & Categories & Farmers $(\%)$ \\
\hline \multirow{2}{*}{ Sex } & Male & 62.3 \\
\hline & Female & 37.7 \\
\hline \multirow{4}{*}{ Age } & $<25$ & 2.8 \\
\hline & $25-44$ & 38.7 \\
\hline & $45-65$ & 51.9 \\
\hline & $>65$ & 6.6 \\
\hline \multirow{4}{*}{ Number of years in school } & - & 9.4 \\
\hline & $1-7$ & 84.0 \\
\hline & $8-13$ & 5.2 \\
\hline & $>13$ & 1.4 \\
\hline \multirow{5}{*}{ Farm size (ha) } & $<0.5$ & 50.5 \\
\hline & $0.5-1.0$ & 27.4 \\
\hline & $1.2-1.5$ & 8.8 \\
\hline & $1.6-2.0$ & 5.7 \\
\hline & $>2.0$ & 7.6 \\
\hline \multirow{2}{*}{ Group membership } & Yes & 39.6 \\
\hline & No & 60.4 \\
\hline \multirow{3}{*}{ Production purpose } & Subsistence & 56.2 \\
\hline & Commercial & 0.9 \\
\hline & Subsistence \& commercial & 42.9 \\
\hline \multirow{2}{*}{ Market accessibility } & Yes & 39.2 \\
\hline & No & 60.8 \\
\hline \multirow{2}{*}{ Seed accessibility } & Yes & 23.1 \\
\hline & No & 76.9 \\
\hline Total & & 100.0 \\
\hline
\end{tabular}

Note. $\mathrm{n}$ : sample size.

\subsection{Adoption Rates of Improved Sorghum Technologies by Farmers}

A range of improved technologies are recommended by stakeholders for sorghum production. These technologies include improved varieties such as NACO Mtama 1, Macia, Tegemeo, Pato and Hakika; insecticides such as Sumithion, Karete and Selecrone; fertilizer application such as NPK (booster), DAP and Urea; threshing machines as one of the post-harvest equipment and optimum seed rate of 7.5 to $8.7 \mathrm{~kg} / \mathrm{ha}$. Some farmers adopted these technologies (Figure 2). Findings show that the agricultural technologies score low adoption rates among farmers. The optimum seed rate (7.2\%) had the least adoption rate followed by use of 
threshing machine (8.4\%). An about $17 \%$ of farmers used inorganic fertilizers. Over $26 \%$ of farmers reported to use insecticides due to high insect infestation especially fall army worms, though most of them couldn't remember the specific names of those insecticides. Seeds of improved varieties were used by about $39 \%$ of farmers compared to other technologies.

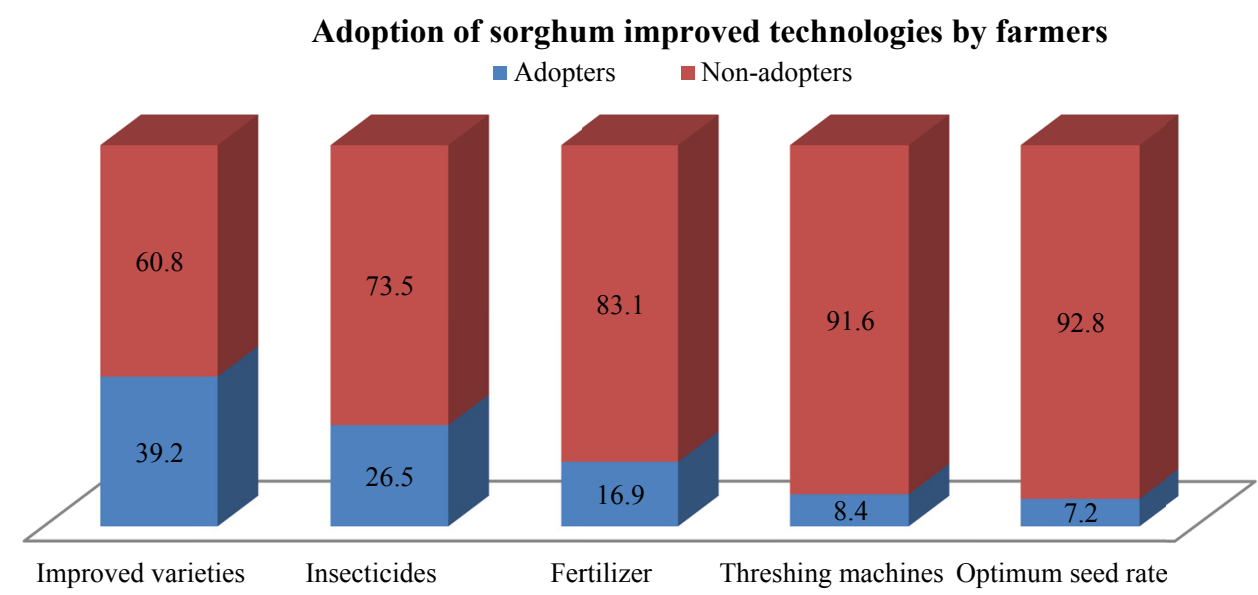

Figure 2. Adoption rates of improved technologies by farmers

\subsection{Adoption of Improved Sorghum Varieties Based on Socio-economic Characteristics}

The distribution of adopters based on sex indicated that most adopters of improved varieties are men compared to women. The adopters aged between 45-65 years had higher adoption rate (23\%) than other age groups. Most adopters have 1-7 years formal school education. Farmers who belonged to farmer groups showed a higher adoption rate of about $21 \%$. Furthermore, farmers who had market outlets for sorghum grain showed higher adoption rate compared to farmers who had no market outlets (Table 4).

Table 4. Socio-economic characterization of adopters of improved varieties $(n=212)$

\begin{tabular}{lll}
\hline Household variables & Categories & Farmers (\%) \\
\hline \multirow{2}{*}{ Sex } & Male & 23.2 \\
& Female & 16.0 \\
\hline Age & $<25$ & 0.9 \\
& $25-44$ & 11.9 \\
& $45-65$ & 23.1 \\
& $>65$ & 3.3 \\
\hline Number of years in school & 0 & 4.2 \\
& $1-7$ & 31.1 \\
& $8-13$ & 3.4 \\
Group membership & $>13$ & 0.5 \\
\hline \multirow{2}{*}{ Market accessibility } & Yes & 20.8 \\
\hline Total & No & 18.4 \\
\hline
\end{tabular}

Note. n: sample size.

\subsection{Adoption Rates of Improved Varieties in Intervention and Non-intervention Areas}

From the findings, higher adoption rate was observed from intervention districts (about 31\%) compared to non-intervention (8.5\%). Among all intervention districts, Singida DC (9\%) had higher adoption rate. However, for non-intervention districts, high adoption rate was observed in Kongwa (8\%) (Table 5). 
Table 5. Adoption rates among farmers in different districts $(\mathrm{n}=212)$

\begin{tabular}{llll}
\hline Intervention & Adoption rate (\%) & Non-intervention & Adoption rate (\%) \\
\hline Singida DC & 9.0 & Kongwa & 8.0 \\
Momba & 8.1 & Tarime & 0.5 \\
Mkalama & 4.7 & & \\
Rombo & 4.2 & & \\
Iramba & 3.3 & & \\
Ikungi & 1.4 & Total & 8.5 \\
\hline Total & 30.7 & & \\
\hline
\end{tabular}

Note. n: sample size.

\subsection{Adoption Rate of Each Improved Sorghum Varieties by Farmers}

Farmers highly adopted NACO Mtama 1 (17\%), Macia (9\%) and Tegemeo (6.6\%) varieties. The varieties that scored below 5\% adoption rate included Pato and Hakika (Table 6). However, very few farmers planted more than one variety.

Table 6. Adoption rates of each improved variety or their combination $(n=212)$

\begin{tabular}{ll}
\hline Improved varieties & Adoption rate (\%) \\
\hline NACO Mtama 1 & 17.0 \\
Macia & 9.0 \\
Tegemeo & 6.6 \\
Pato & 4.2 \\
Hakika & 0.9 \\
Both Pato \& Tegemeo & 0.5 \\
Both Pato \& Macia & 0.5 \\
Both Macia \& Tegemeo & 0.5 \\
\hline Total & 39.2 \\
\hline
\end{tabular}

Note. n: sample size.

Furthermore, non-adopters of improved varieties reported several reasons for not using improved seeds and acknowledged highly on unavailability of these seeds, followed by inaccessibility, high seed prices, unreliable grain markets and lack of knowledge of improved seeds. These main reasons contribute to low adoption among smallholder farmers (Table 7).

Table 7. Reasons to low adoption of improved varieties among farmers $(n=212)$

\begin{tabular}{ll}
\hline Reason & Farmers (\%) \\
\hline Seeds unavailability & 25.9 \\
Seeds inaccessibility & 24.1 \\
High seed prices & 6.6 \\
Lack of reliable markets & 2.4 \\
Lack of reliable knowledge & 1.8 \\
\hline Total & 60.8 \\
\hline
\end{tabular}

Note. n: sample size.

\subsection{Probit Determinants of Improved Sorghum Technologies by Farmers}

The Table 8 shows the estimated results of the probit models regarding the factors influencing adoption of each improved technology. The empirical estimations have been done by the maximum likelihood with the model being highly significant at $1 \%$. The results of all chi-square $\left(\mathrm{X}^{2}\right)$ statistics were highly significant $(\mathrm{p}<0.000)$ indicating that the models had strong explanatory power. The number of years of formal education, group membership, availability of free seed, grain market accessibility and seed accessibility positively influenced farmers to adopt seeds of improved sorghum. This implies that for every unit increase in any of these variables, 
the adoption probability increases by the magnitude of their marginal effects, i.e., $19.9 \%, 1 \%, 26.5 \%, 21.2 \%$ and $46.1 \%$ for years of formal education, group membership, free seeds, grain market accessibility and seed accessibility, respectively.

For optimum seed rate, the age and sex negatively influenced its adoption. This implies that for every unit increase in age, adoption rate decreases by $0.3 \%$; also being female decreased adoption rate by $0.7 \%$. Sex, farm size, grain prices and seed accessibility positively influenced adoption of inorganic fertilizer (Table 8). A unit increase in any of these variables increases adoption probability for fertilizer by $8.5 \%, 2.4 \%, 0.1 \%$ and $13.1 \%$, respectively. Age and seed accessibility positively influenced adoption of insecticides, implying that a unit increase in each of these variables increases its adoption by $4.1 \%$ and $15.9 \%$ respectively. Furthermore, group membership positively influenced the use of threshing machines with a unit increase resulting to increase in adoption by $80.4 \%$.

Table 8. Probit determinants of stated adoption of improved sorghum technologies

\begin{tabular}{|c|c|c|c|c|c|}
\hline Variables & Improved seeds & Seed rate & Fertilizer & Insecticides & Threshing machines \\
\hline Age & 0.003 & $-0.189(-0.0029594)^{*}$ & 0.001 & $0.01865(0.041227)^{*}$ & -0.00016 \\
\hline Sex & -0.139 & $-0.49463(-0.0770707)^{*}$ & $0.64465(0.0850377)^{*}$ & 0.15803 & -0.15006 \\
\hline Years in school & $0.767(0.198857)^{*}$ & 0.14371 & 1.21476 & 0.63062 & -0.17464 \\
\hline Group membership & $0.38567(0.099961)^{*}$ & -0.06163 & 0.29190 & -0.35189 & $0.43677(0.804291)^{*}$ \\
\hline Purpose & 0.48831 & 0.23365 & -0.42610 & -0.0718 & -0.25228 \\
\hline Farm size & 0.08424 & -0.19493 & $0.18260(0.0240875)^{*}$ & 0.00770 & -0.05377 \\
\hline Seed price & 0.00006 & -0.00020 & -0.00008 & 0.00001 & -0.00020 \\
\hline Free seeds & $1.02244(0.2650039)^{* *}$ & -0.25148 & -1.10199 & 0.01444 & 0.2011 \\
\hline Grain market & $-0.81899(-0.2122738)^{* *}$ & -0.81497 & -0.3345 & -0.06386 & -0.12917 \\
\hline Grain price & 0.00081 & 0.00021 & $0.00145(0.0001922)^{* *}$ & 0.00025 & 0.00087 \\
\hline Seed accessibility & $1.77920(0.4611495)^{* * *}$ & 0.54191 & $0.99190(0.130844)^{* *}$ & $0.72010(0.1591384)^{* *}$ & -0.37338 \\
\hline Pseudo R2 & 0.3071 & 0.1126 & 0.1589 & 0.0933 & 0.0696 \\
\hline LR chi2 & 87.15 & 15.42 & 19.58 & 17.42 & 10.71 \\
\hline
\end{tabular}

Note. ${ }^{* * *}$ significant at $1 \%,{ }^{* *}$ significant at $5 \%,{ }^{*}$ significant at $10 \%$.

$\mathrm{R}^{2}$ : regression; LR: Linear regression; $\mathrm{chi}^{2}$ : chi square, values in parenthesis are marginal effects.

\subsection{Gross Margin for Adopters and Non-adopters of Improved Sorghum Varieties}

The two groups differed in gross margin as well as input costs (Table 9). Both groups incurred high seed costs, although much higher costs were observed among non-adopters. Moreover, adopters incurred higher fertilizer costs, weeding costs, ridging costs and transportation costs while non-adopter incurred higher costs for insecticides, harvesting, security, threshing and winnowing, as well as grading and packaging costs. Furthermore, for both groups the average, the gross margin values were positive with much higher gross margin observed for adopters (822,288 Tshs/ha) than non-adopters (374,363 Tshs/ha). 
Table 9. Gross margin among adopters and non-adopters of improved varieties

\begin{tabular}{|c|c|c|}
\hline Variable costs (Tshs/ha) & Adopters & Non-adopters \\
\hline Rented land & 195319.76 & 160852.71 \\
\hline Land preparation & 72994.18 & 69336.24 \\
\hline Seed & 39329.94 & 54504.84 \\
\hline Fertilizer & 17718.02 & 5687.98 \\
\hline Insecticides & 11380.81 & 14529.07 \\
\hline Weeding & 93546.51 & 61937.98 \\
\hline Ridging & 8575.58 & 2228.68 \\
\hline Threshing and winnowing & 24139.53 & 27074.61 \\
\hline Harvesting & 4229.65 & 8412.79 \\
\hline Transportation & 27848.84 & 26346.89 \\
\hline Security & 14651.16 & 17461.24 \\
\hline Grading & 6468.02 & 10218.02 \\
\hline Packaging & 14777.88 & 15294.89 \\
\hline Average Total Variable Costs (TVC) & 530980.41 & 473885.91 \\
\hline Average yield $(\mathrm{kg})$ & 3185.81 & 2163.68 \\
\hline Average Price (Tshs) & 424.78 & 392.04 \\
\hline Average Gross Revenue & 822287.962 & 374363.197 \\
\hline
\end{tabular}

Note. 1 USD $=2315$ Tshs.

\section{Discussion}

\subsection{Adoption of Improved Sorghum Technologies}

Technology adoption is a vital component when one thinks of investing in agriculture. Improved technologies prove to be beneficial to farmers in many ways. The advantages that come with improved varieties include early maturing, resistance to environmental stresses and high yields. Fertilizer application increases crop yield on poor soil. Insecticide application helps to control insect damage and secure good yield for farmers. Threshing machine saves physical labor. Optimum seed rate is usually recommended since it ensures proper crop growth to provide high productivity. However, these technologies can be expensive for farmers and for some technologies such as fertilizers and insecticides, it can lead to plant and soil fertility damage if excessively used. In developing countries, new technologies are characterized by low adoption especially if high investment is required (Yigezu et al., 2018). Farm profitability depends on the use of recommended improved technologies (Liu et al., 2014). Developing and promoting adoption of these yield increasing technologies is suitable to improve farmers' livelihood (Ghimire et al., 2015). From the study, young farmers were more receptive towards practices such as optimum seed rate since they are believed to be less conservative than older farmers. This was probably because many young farmers participated in farmer groups and field demonstrations since they are less experienced, but also they easily grasped knowledge of different practices. The study corroborates Huang et al. (2018) who noted that young farmers with less farming experience adopted recommended practices easily. The younger generation has more school experience, more innovative and more exposure to information than the older generation (Melesse, 2018). Evidence from Kaliba et al. (2018) also suggests that young farmers who are already exposed to improved technologies are increasingly adopting these technologies. The majority of young farmers can easily find information and accept change easily. But also, this does not mean that older farmers lack intuition, knowledge and circumstances to know benefits of new technologies. This is consistent with the fact that the majority of farmers were experiencing high insect infestation that needed insecticides use. Recently, Tanzania is experiencing climatic modifications, and biotic and abiotic stresses. Speedy climatic changes push even older farmers to new technologies to help them despite their farming experience (Kansiime et al., 2014).

Practices such as optimum seed rate was easily followed by women probably because most of them actively belonged to different farmer groups and also participate in group farming activities. On the other hand, women become less receptive in adopting some technologies especially if these technologies are expensive. This finding corroborates Mensah (2018) who noted that men were likely to adopt inorganic fertilizer than women because most of male-headed households had access to household resources and wealthier than female-head households. Addison et al. (2018) also argued that women were disadvantaged regarding improved variety seeds and fertilizer due to limited resource ownership. This suggests for need to address gender-related issues that enhance female participation in adoption of improved technologies. Furthermore, Theriault et al. (2017) also suggests to 
better understand the gender differences to technology adoption so as to bridge the gender gap while promoting increasing productivity levels.

Positive association between adoption of improved varieties and years of formal education of farmer was probably because with more years of formal education, farmers become less reluctant to accept changes. The study corroborates earlier literature (Ghimire et al., 2015; Chandio \& Yuansheng, 2018; Kaliba et al., 2018) that suggest that with increased years of formal education, a farmer is more likely to process new information more rapidly than others. The majority of farmers in most rural areas in Tanzania lack formal education that is also seen as an important component in learning most agricultural skills. Moreover, this implies that there is need of formal education and information that will help farmers evaluate and appreciate benefits of new technologies. The findings also support Tsnigo and Behrman (2017) who suggested that adequate knowledge is important to farmers to comprehend economic incentives of improved technologies.

Belonging to farmer groups increased the chance of adopting improved variety seed and threshing machines probably due to easy accessibility of these technologies in groups through demonstrations, trainings, and even easier access to machines to group members. Often, extension officers disseminate seeds to farmers in groups as they use them as instrument for awareness creation and new technology popularization. Danso et al. (2017) argued that FBOs increased chances of adoption of improved variety seeds by farmers since social capital networks among farmers are vital for adoption. But also, it is easier for machinery equipment to be disseminated among groups for farmers to share than individual farmers since they are high investment technologies (Kolade \& Harphram, 2014). Khondoker et al. (2016) also noted that farmer groups in India minimized barriers to technology accessibility for poor smallholder farmers. Moreover, farmer groups were seen to be effective to channel opportunities from public and private stakeholders. Therefore, more intervention programs should consider forming, strengthening and expanding farmer groups for better adoption and increased agricultural production (Kolade \& Harphram, 2014).

Farmer with larger farm sizes may be able to strictly follow recommended practices like fertilizer application to avoid unnecessary losses. Most farmers with smaller farm sizes in Tanzania are poor and fail to afford agricultural inputs. The adoption of fertilizer among many smallholder farmers is largely affected by financial constraint (Martey et al., 2014). Most farmers with larger farm sizes may be wealthier, risk takers but also, they are likely to have opportunities to learn about new technologies (Oladeji et al., 2015; Chandio \& Yuansheng, 2018).

The availability of free seeds motivated farmers to adopt improved varieties probably because they don't incur seed costs. In some cases, farmers obtained free seeds from public research institutes and development organizations. The majority of adopters $(30.7 \%)$ from intervention districts easily accessed seeds compared to non-intervention districts $(8.5 \%)$. This implies that with the project intervention (HOPE II) seed accessibility was simplified to some farmers. But also, this does not necessarily mean that if seeds are freely available to some farmers then they will easily obtain other inputs regardless the prices. It is important to pinpoint that seed accessibility may also affect adoption of other technologies example inorganic fertilizer and insecticides. If seeds are accessible at the right time, then farmers will not only adopt improved seeds but also complementary technologies, which should also be affordable. Purchase and cultivation of improved variety seeds by farmers is also simplified by seeds availability in local stores (Ghimire et al., 2015). Strengthening investments in good seed storage will help farmers in emergency times such as drought or flood stresses (McGuire and Sperling, 2016). Accessibility of agricultural inputs to farmers should be improved as well as enabling environment for both public and private suppliers (Kaliba et al., 2018). Chandio and Yuansheng (2018) further suggests that institutional linkages among seed companies, agricultural input dealers, extension services and service providers should be strengthened.

Reliable markets motivate farmers to adopt seed of improved varieties for more production since they do not incur extra expenses to search for markets (Alemaw, 2014). Sorghum grain produced by farmers is mainly for consumption and the industrial demand is increasing for food, beverage and animal feed industries (Sani et al., 2013; Titilola et al., 2018). In the study area, about $25 \%$ of all adopters (39.2\%) of improved variety seeds had access to grain markets. This implies that with reliable market channels, farmers are more willing to adopt improved seeds because they know they have reliable points to sell what they produce. High grain prices also created an incentive for farmers to use fertilizer. This was probably because farmers become profit-assured when grain price is high. Onyeneke (2017) suggests that with agricultural inputs, farmers should receive more knowledge about improved sorghum technologies through steady flow of information so as to maintain high productivity levels, reliable market and favorable market prices. 


\subsection{Profitability of Sorghum Production by Farmers}

Adopters of improved sorghum varieties obtained higher gross margin probably due to high average price, use of complementary technologies, resistance capacity of these varieties especially to drought, insects, pests and diseases as well as high yields capacity. Farmers growing obsolete varieties obtained lower profitability levels compared to improved varieties. This is due to lower yields and sensitivity to various stresses. Aloyce et al. (2017) noted negative returns for small scale farmers in Tanzania growing sorghum obsolete varieties. In most, cases obsolete varieties have late maturity and are highly affected by low rainfalls leading to low grain yield (Mwamahonje \& Maseta, 2018). Non-adopters of improved varieties also used other agricultural technologies, and this may be due to several factors such as increasing climatic stresses, accessibility and affordability of some technologies in certain production seasons. Farmers cultivating obsolete varieties incurred higher seed costs since most of them broadcast seed as planting method, which requires lot of seeds. Most non-adopters do not follow recommended optimum seed rate $(7.5$ to $8.7 \mathrm{~kg} / \mathrm{ha})$. These results are similar to the study by Obayelu and Ajayi (2018) who noted higher seed costs being incurred by farmers broadcasting sorghum, most of them growing old varieties. Adopters of improved varieties incurred less seed costs probably because most of them obtained free seeds from extension officers and research institutions but also use good agronomic practices. Non-adopters incurred higher insecticides costs compared to adopters may be due to low resistance ability of varieties that forced them to use insecticides. Sorghum production being highly affected by insects, especially fall army worms, this has obliged farmers to stretch themselves at least to buy these insecticides to minimize grain losses. Kansiime et al. (2014) argue that with environmental stresses affecting production many farmers are forced to use some improved technologies to avoid losses.

Sorghum improved varieties have best production and marketing attributes such as desirable maturity periods, good grain yield capacity, premium market prices and shortest cooking time (Timu et al., 2014). Most farmers in the study area preferred NACO Mtama 1 and Macia varieties because of the high yield and drought resistance traits while Tegemeo variety was preferred due to early maturity trait. These varieties have attractive colors and were highly demanded in the market due to palatability, and most importantly, they highly meet specification for brewing purpose. The study corroborates Aloyce et al. (2017) who noted that NACO Mtama 1 and Macia varieties preference are attributed to market opportunities by the growing demand especially from the brewery industry. Macia and Tegemeo varieties were the most preferred in the market that also drove higher adoption rates by farmers (Mafuru et al., 2008). Adoption of improved varieties results from favorable production and marketing traits such as taste, brewing and cooking qualities (Gesare et al., 2014). Aloyce et al. (2017) suggests that breeders should consider all traits when developing new improved varieties so as to capture the market needs. Sorghum production needs investments especially for improved varieties as well as the whole commodity value chain. Furthermore, investing on breeding technologies, seeds accessibility and facilitation of other production inputs are important steps to improve adoption rates, profitability and income among farmers (Mrema et al., 2016).

\section{Conclusion}

The adoption studies that evaluated factors leading to adoption decision of different improved technologies among farmers mainly focus in improving farmers yield and profitability. It is believed that with these technologies, farmers can make positive changes for themselves as well as the agricultural sector. In this study, low adoption rates of analyzed technologies were revealed. Factors underlining the adoption of these technologies were also investigated to identify key areas for improvement of sorghum value chain. Probit estimates revealed that age, sex, years in school, group membership, farm size, availability of free seeds, seed accessibility, grain market and grain prices significantly influenced farmer adoption decision. These factors may impact farmers differently in different geographical locations and this call for more adoption studies across various conditions where farmers are operating. This study used probit model for adoption analysis as it simplifies the analysis since it goes beyond the Ordinary Least Square (OLS) analysis. There is need for strategic investments in different sorghum technologies in addition to seed of improved varieties since higher profitability is observed among adopters of improved varieties who use some allied technologies as well. This would also encourage non-adopters to use quality seed which will be easy only if these seeds are available and accessible. Stakeholders are expected to influence enactment of relevant policies especially the ones incentivizing not only seed inputs dealers but also other complementary technologies and minimize farmers' production costs. Commercial environment is then crucial since most sorghum farmers are subsistence growers and fail to acquire most inputs. It is believed that when marketing chances and prices get improved, farmers can afford these inputs as well as improving their profitability levels. 


\section{References}

Addison, M., Aidoo, R., \& Ohene-Yankyera, K. (2018). Gender Effect on Adoption of Selected Improved Rice Technologies in Ghana. Journal of Agricultural Science, 10(7), 390. https://doi.org/10.5539/jas.v10n7p390

Alemaw, A. T. (2014). Impact of improved maize varieties adoption on smallholder farmers' marketed maize surplus in Oromia regional state, Ethiopia ( $\mathrm{PhD}$ thesis, Sokoine University of Agriculture).

Aloyce, R. K., Mazvimavi, K., \& Ghirmay, S. (2017). Economic Profitability and Risk Analyses of Improved Sorghum Varieties in Tanzania. Journal of Development and Agricultural Economics, 9(9), $250-68$. https://doi.org/10.5897/JDAE2017.0833

Awotide, B., Karimov, A., \& Diagne, A. (2016). Agricultural Technology Adoption, Commercialization and Smallholder Rice Farmers' Welfare in Rural Nigeria. Agricultural and Food Economics, 4, 3. https://doi.org/10.1186/s40100-016-0047-8

CCAFS (Climate Change, Agriculture and Food Security). (2016). Annual Report 2015: Change for the better. Copenhagen, Denmark: CGIAR Research Program on Climate Change, Agriculture and Food Security.

Chandio, A., \& Yuansheng, J. (2018). Determinants of Adoption of Improved Rice Varieties in Northern Sindh, Pakistan. Rice Science, 25(2), 103-110. https://doi.org/10.1016/j.rsci.2017.10.003

Danso, G., Bosiako, J., Ehiakpor, D., \& Mabe, F. (2017). Adoption of Improved Maize Variety among Farm Households in the Northern Region of Ghana. Cogent Economics \& Finance, 5(1), 1416896. https://doi.org/10.1080/23322039.2017.1416896

Diiro, G., Ker, A., \& Sam, A. (2015). The Role of Gender on Fertilizer Adoption in Uganda. African Journal of Agricultural and Resource Economics, 10(2), 117-130.

Elsheikh, S., Hashim, A., Faki, H., \& Elamin, E. (2018). Factors Affecting Adoption of Improved Varieties of Sorghum, Millet, Groundnut, and Sesame in North Kordofan State. Agricultural Research and Technology: Open Access Journal, 13(4), 555889. https://doi.org/10.19080/ARTOAJ.2018.13.555889

Engwali, F., Dinga, L., \& Chotangui, A. (2019). Comparative Analysis of Improved Maize (Zea mays L.) Seeds Adoption on Smallholder Farmers' Performance in Fako Division, South West Region, Cameroon. Economics, 4(6), 267-274. https://doi.org/10.11648/j.ijae.20190406.13

FAO (Food and Agricultural Organization). (2018). Food Security Statistics. Rome, Italy. Retrieved from http://www.fao.org/economic/ess/ess-fs/en

Feder, G., \& Umali, D. (1993). The adoption of agricultural innovations: A review. Technology Forecast Soc. Change, 43, 215-39. https://doi.org/10.1016/0040-1625(93)90053-A

Feder, G., Just, E., \& Zilberman, D. (1985). Adoption of Agricultural Innovations in Developing Countries: A survey. The University of Chicago. Journal of Economic Development and Cultural Change, 33, $255-297$. https://doi.org/10.1086/451461

Ghadim, A., \& Pannell, D. (1999). A Conceptual Framework of Adoption of an Agricultural Innovation. Agricultural Economics, 21, 145-154. https://doi.org/10.1111/j.1574-0862.1999.tb00590.x

Ghimire, R., Wen-Chi, H., \& Shrestha, R. B. (2015). Factors Affecting Adoption of Improved Rice Varieties among Rural Farm Households in Central Nepal. Rice Science, 22(1), 35-43. https://doi.org/10.1016/j.rsci. 2015.05.006

Gujarati, D. (2004). Basic econometrics (4th ed., p. 1001). McGraw-Hill, New York.

Huang, Z., Sunny, F., \& Karimanzira, T. (2018). Investigating Key Factors Influencing Farming Decisions Based on Soil Testing and Fertilizer Recommendation Facilities (STFRF): A Case Study on Rural Bangladesh. GCB Bioenergy, 7, 1176-1184.

Kaliba, A., Mazvimavi, K., Gregory, T., \& Mgonja, M. (2018). Factors Affecting Adoption of Improved Sorghum Varieties in Tanzania under Information and Capital Constraints. Agricultural and Food Economics, 6(18), 21. https://doi.org/10.1186/s40100-018-0114-4

Kalinda, T., Tembo, G., Kuntashula, E., \& Lusaka, Z. (2014). Adoption of Improved Maize Seed Varieties in Southern Zambia. Asian Journal of Agricultural Sciences, 6(1), 33-39. https://doi.org/10.19026/ajas.6.4851

Kansiime, M., Wambugu, S. K., \& Shisanya, C. A. (2014). Determinants of Farmers' Decisions to Adopt Adaptation Technologies in Eastern Uganda. Journal of Economics and Sustainable Development, 5(3), 189-199. 
Kehinde, A., \& Adeyemo, R. (2017). A Probit Analysis of Factors Affecting Improved Technologies Dis-adoption in Cocoa-based Farming Systems of Southwestern Nigeria. Int J Agric Econ, 2(2), 35-41. https://doi.org/10.11648/j.ijae.20170202.12

Khondoker, A., Mottaleb, K., Krupnik, T., \& Erenstein, O. (2016). Factors Associated with Small-scale Agricultural Machinery Adoption in Bangladesh: Census findings. Journal of Rural Studies, 46, 155-168. https://doi.org/10.1016/j.jrurstud.2016.06.012

Kolade, O., \& Harphram, T. (2014). Impact of Cooperative Membership on Farmers' Uptake of Technological Innovations in Southwest Nigeria, Development Studies Research, 1(1), 340-353. https://oi.org/10.1080/ 21665095.2014.978981

Liu, H., Ren, L., Spiertz, H., Zhu, Y., \& Xie, G. (2014). An Economic Analysis of Sweet Sorghum Cultivation for Ethanol Production in North China. Gcb Bioenergy, 7(5), 1176-84. https://doi.org/10.1111/gcbb.12222

Mafuru, J. M., Norman, D. W., \& Fox, J. S. (2008). Consumer perception of sorghum variety attributes in the Lake Zone Tanzania. AAAE Conference Proceedings, 2007, 171-176. https://doi.org/10.22004/ag.econ. 52079

Martey, E., Wiredu, A., Etwire, P., Fosu, M., Buah, S., Bidzakin, J., \& Kusi, F. (2014). Fertilizer Adoption and Use Intensity among Smallholder Farmers in Northern Ghana: A case study of the AGRA soil health project. Sustainable Agriculture Research, 3(1), 24. https://doi.org/10.5539/sar.v3n1p24

McGuire, S., \& Sperling, L. (2016). Seed systems smallholder farmers use. Food Security, 8(1), $179-195$. https://doi.org/10.1007/s12571-015-0528-8

Melesse, B. (2018). A Review on Factors Affecting Adoption of Agricultural New Technologies in Ethiopia. Journal of Agricultural Science and Food Research, 9(3), 4.

Mensah, M., Villamor, G., \& Vlek, P. (2018). Gender Specific Determinants of Inorganic Fertilizer Adoption in the Semi-arid Region of Ghana. West African Journal of Applied Ecology, 26, 179-192.

Mpangwa, M. (2011). Adoption and economic impacts of improved sorghum varieties in semi-arid areas of Tanzania: A case of Singida rural district (MSc. Thesis, Agricultural Economics of Sokoine University of Agriculture).

Mrema, E., Shimelis, H., Laing, M., \& Lugendo, B. (2016). Farmers' Perceptions of Sorghum Production Constraints and Striga Control Practices in Semi-arid Areas of Tanzania. International Journal of Pest Management, 63(2), 146-156. https://doi.org/10.1080/09670874.2016.1238115

Msangi, H. (2017). Examining the inverse relationship between farm size and efficiency in Tanzanian Agriculture (Doctoral dissertation, Sokoine University of Agriculture).

Muyanga, M., \& Jayne, T. (2017). Can smallholder farm themselves out of smallholder farming and poverty? Department of Agricultural, Food and Resources Economics, Michigan State University, USA.

Mwamahonje, A., \& Maseta, Z. (2018). Evaluation of yield performance of sorghum (Sorghum bicolor L. Moench) varieties in Central Tanzania. International Journal of Agronomy and Agricultural Research, 13(2), 8-14.

Nicholson, W., \& Snyder, C. (2008). Microeconomic theory: Basic principles and extensions. Mason, Ohio: Thomson/South-Western.

Obayelu, A., \& Ajayi, D. (2018). Economic Impact and Determinants of Adoption of Improved Maize Production Technologies. Journal of Agricultural Sciences, 63(2), 217-228. https://doi.org/10.2298/JAS 18022170

Ojo, S., \& Ogunyemi, I. (2014). Analysis of Factors Influencing the Adoption of Improved Cassava Production Technology in Ekiti State, Nigeria. International Journal of Agricultural Sciences and Natural Resources, 1 , 40-44.

Oladeji, O. O., Okoruwa, V. O., Ojehomon, V. E. T., Diagne, A., \& Obasoro, O. A. (2015). Determinants of Awareness and Adoption of Improved Rice varieties in North Central, Nigeria. Rice Genomics and Genetics, $6(7), 1-10$.

Onyeneke, R. (2017). Determinants of Adoption of Improved Technologies in Rice Production in Imo State, Nigeria. African Journal of Agricultural Research, 12, 888-896. https://doi.org/10.5897/AJAR2016.11737 
Orr, A., Mwema, C., Gierend, A., \& Nedumara, S. (2016). Sorghum and millets in Eastern and Southern Africa. Facts, trends and outlook. ICRISAT Research Program, Markets, Institutions and Policies Working Paper Series No. 62. International Crops Research Institute for the Semi-Arid Tropics, Patancheru.

Petry, J., Sebastio, S., \& Martins, E. (2019). Innovation and the Diffusion of Technology in Agriculture in Floodplains in the State of Amazonas. Revista de Administração Contemporânea, 23(5), 619-635. https://doi.org/10.1590/1982-7849rac2019190024

Rao, B., Mukherjee, D., Devi, Y., \& Tonapi, V. (2017). An Economic Analysis of Improved Rabi Sorghum Cultivars in Rainfed Situation of Maharashtra, India. Int. J. Curr. Microbiol. App. Sci., 2017(SP4), 7-15.

Rogers, E. (2003). Diffusion of Innovations (5th ed.). Free Press: New York.

Rogers, E., \& Stanfield, D. (1968). Adoption and diffusion of new products. In F. Bass, C. W. King, \& E. A. Pessemier (Eds.), Applications of the Sciences in Marketing Management. New York: John Wiley.

Sani, R. M., Haruna, R., \& Sirajo, S. (2013). Economics of Sorghum (Sorghum bicolor (L.) Moench) Production in Bauchi Local Government Area of Bauchi State, Nigeria (No. 309-2016-5156).

Simtowe, F., \& Mausch, K. (2018). Who is Quitting? An Analysis of the Dis-adoption of Climate Smart Sorghum Varieties in Tanzania. International Journal of Climate Change Strategies and Management, 11(3), 341-357. https://doi.org/10.1108/IJCCSM-01-2018-0007

Theriault, V., Smale, M., \& Haider, H. (2017). How Does Gender Affect Sustainable Intensification of Cereal Production in the West African Sahel? Evidence from Burkina Faso. World Development, 92, 177-191. https://doi.org/10.1016/j.worlddev.2016.12.003

Timu, A., Mulwa, R., Okello, J., \& Kamau, M. (2014). The Role of Varietal Attributes on Adoption of Improved Seed Varieties: The case of Sorghum in Kenya. Agriculture \& Food Security, 3(1), 9. https://doi.org/ 10.1186/2048-7010-3-9

Titilola, M., Marangu, D., \& Olayide, O. (2018). Assessment of Impact of Sorghum for Multiple Uses (SMU) Value Chain Project on Smallholder Farmers in Eastern Kenya. African Journal of Sustainable Development, 8(1), 109-129.

Tsinigo, E., \& Behrman, J. (2017). Technological Priorities in Rice Production among Smallholder Farmers in Ghana. NJAS-Wageningen Journal of Life Sciences, 83, 47-56. https://doi.org/10.1016/j.njas.2017.07.004

Ugochukwu, A., \& Phillips, P. (2018). Technology Adoption by Agricultural Producers: A Review of the Literature. In N. Kalaitzandonakes, E. Carayannis, E. Grigoroudis, \& S. Rozakis (Eds.), From Agriscience to Agribusiness. Innovation, Technology, and Knowledge Management. Springer, Cham. https://doi.org/ 10.1007/978-3-319-67958-7_17

URT (United Republic of Tanzania). (2016). Value Chain Roadmap for Pulses 2016-2020 (p. 82).

Wango, V., Mburu, J., Nyikal, R., \& Onwong'a, R. (2016). An analysis of profitability and factors influencing adoption of agro-ecological intensification (aei) techniques in Yatta sub-county, Kenya (No. 1720-2018-1425).

World Bank. (2015). Tanzania Mainland Poverty Assessment Report. Retrived from http://www.worldbank.org/ tanzania

Yamane, T. (1967). Elementary sampling theory (pp. x-405). Englewood Cliffs, New Jersey: Prentice-Hall, Inc.

Yigezu, A., Mugera, A., El-Shater, T., Aw-Hassan, A., Piggin, C., Haddad, A., Khalil, Y., \& Loss, S. (2018). Enhancing Adoption of Agricultural Technologies Requiring High Initial Investment among Smallholders. Technological Forecasting and Social Change, 134, 199-206. https://doi.org/10.1016/j.techfore.2018.06.006

\section{Copyrights}

Copyright for this article is retained by the author(s), with first publication rights granted to the journal.

This is an open-access article distributed under the terms and conditions of the Creative Commons Attribution license (http://creativecommons.org/licenses/by/4.0/). 